JOTE Volume 2 Nomor 1 Tahun 2020 Halaman 25-38

JOURNAL ON TEACHER EDUCATION

Research \& Learning in Faculty of Education

\title{
PERANAN GURU YANG TELAH DISERTIFIKASI DALAM MENINGKATKAN MUTU PEMBELAJARAN DI SEKOLAH DASAR NEGERI 011 SUKAJADI PEKANBARU
}

\author{
Henri Yanto Daulay \\ Program Studi Pendidikan Ekonomi, STKIP ‘Aisyiyah Riau \\ Email : henridaulay201113@gmail.com
}

\begin{abstract}
Abstrak
Peran guru dalam meningkatkan mutu pembelajaran menjadi penting karena salah satu unsur dalam mengembangkan atau tercapainya tujuan pendidikan nasional adalah kemampuan guru dalam memberikan pembelajaran di sekolah. Tujuan penelitian ini adalah Pelaksanaan kompetensi pedagogik, kompetensi kepribadian, kompetensi professional dan kompetensi sosial oleh guru-guru yang sudah disertifikasi dalam meningkatkan mutu pembelajaran di SD Negeri 011 Sukajadi Pekanbaru. Untuk memperoleh pemahaman tentang persoalan tersebut maka maka peneliti menggunakan pendekatan kualitatif. Hasil penelitian ini mengungkapkan bahwa guru-guru yang sudah disertifikasi di SDN 011 Sukajadi Pekanbaru telah menerapkan kompetensi pedagogik dapat lihat pada silabus, RPP, metode yang dipakai dan evaluasi pembelajaran dalam kegiatan belajar mengajar. Kompetensi kepribadian dapat dilihat dari sikap dan kebribadian guruguru yang telah disertifikasi dalam menegakkan kedisiplinan, arif, berwibawa. Kompetensi professional dapat dilihat dari peningkatan nilai hasil belajara siswa dari tahun ketahun mengalami peningkatan dan kompetensi sosial dapat dilihat dari hubungan antara guru-guru yang sudah disertifikasi dengan murid, guru yang belum disertifikasi, kepala sekolah, pegawai tata usaha dan penjaga sekolah terjalin dengan baik dan harmonis.
\end{abstract}

\section{Kata kunci: Guru, Sertifikasi, Mutu Pembelajaran}

\begin{abstract}
The role of teachers in improving the quality of learning is important because one of the elements in building or achieving national education goals is the ability of teachers to provide learning in schools. The purpose of this research is the application of pedagogical competence, personality competence, professional competence and social competence by certified teachers in improving the quality of learning at SD Negeri 011 Sukajadi Pekanbaru. To understand this problem, researchers used a qualitative approach. The results of this study reveal that teachers who have been certified at SDN 011 Sukajadi Pekanbaru have implemented pedagogical competence, which can be seen in the syllabus, lesson plans, the methods used and the evaluation of learning in teaching and learning activities. Personality competence can be seen from the attitudes and personalities of certified teachers in upholding discipline, wisdom, and dignity. Professional competence can be seen from the increase in the value of student
\end{abstract}


learning outcomes from year to year and has increased and social competence can be seen from the relationship between certified teachers and students, teachers who are not certified, school principals, administrative staff and school custodians are well established and harmonious.

Keywords: Teacher, Certification, Quality of Learning

\section{PENDAHULUAN}

Krisis multidimensional yang melanda negeri ini membuka mata kita terhadap mutu pendidikan manusia Indonesia. Itupun dengan sumber daya manusia hasil pendidikan yang ada di negeri ini. Memang, penyebab krisis itu sendiri begitu kompleks. Namun tidak bisa dipungkiri bahwa penyebab utamanya adalah sumber daya manusia itu sendiri yang kurang bermutu. Jangan harap bicara soal profesionalisme, terkadang sikap manusia Indonesia yang paling merisaukan adalah seringnya bertindak tanpa moralitas. Dalam sebuah penelitian, diuangkapkan bahwa produktivitas manusia Indonesia begitu rendah. Hal ini dikarenakan kurang percaya diri, kurang kompetitif, kurang kreatif dan sulit berprakarsa sendiri. Tentunya, hal itu disebabkan oleh sistem pendidikan yang top down, dan yang tidak mengembangkan inovasi dan kreativitas.

Kualiatas mutu pendidikan kita sudah bertahun-tahun, untuk kesekian kalinya kurikulum dituding sebagai penyebabnya. Hal ini tercermin dengan adanya upaya mengubah kurikulum mulai kurikulum 1975 diganti dengan kurikulum 1984, kemudian diganti lagi dengan kurikulum 1994. Kurikulum 1994 pun belum mampu mendongkrak mutu dan akhirnya lahirlah kurikulum 2004 (KBK) dan sekarang berubah lagi menjadi Kurikulum Tingkat Satuan Pendidikan (KTSP). Padahal kalau kita mau jujur rendahnya mutu pendidikan bukan disebabkan oleh kurikulum melainkan disebabkan oleh profesionalisme guru.

Arifin (2000) mengemukakan guru yang profesional harus memenuhi beberapa persyaratan antara lain harus mempunyai: (1) dasar ilmu yang kuat sebagai pengejawantahan terhadap masyarakat teknologi dan masyarakat ilmu pengetahuan, (2) penguasaan kiat-kiat profesi berdasarkan riset dan praksis pendidikan yaitu ilmu pendidikan sebagai ilmu praksis bukan hanya merupakan konsep-konsep belaka. Pendidikan merupakan proses yang terjadi di lapangan dan bersifat ilmiah, serta riset pendidikan hendaknya diarahkan pada praksis pendidikan masyarakat Indonesia; (3) pengembangan kemampuan profesional berkesinambungan, profesi guru merupakan profesi yang berkembang terus menerus dan berkesinambungan antara LPTK dengan praktek pendidikan.

Dengan adanya persyaratan profesionalisme guru ini, perlu adanya paradigma baru untuk melahirkan profil guru Indonesia yang profesional yaitu; (1) memiliki kepribadian yang matang dan berkembang; (2) penguasaan ilmu yang kuat; (3) keterampilan untuk membangkitkan peserta didik kepada sains dan teknologi; dan (4) pengembangan profesi secara berkesinambungan. Keempat aspek tersebut merupakan satu kesatuan utuh yang tidak dapat dipisahkan dan ditambah dengan usaha lain yang ikut mempengaruhi perkembangan profesi guru yang profesional. 
Guru yang profesional dalam melakukan pembelajaran harus dapat memberikan peluang dan tantangan yang besar bagi perkembangan profesionalnya, Meskipun kebutuhan untuk merawat, mengasuh, menyayangi dan mengembangkan anak-anak kita secara maksimal itu akan selalu tetap berada dalam genggaman pengajaran, tuntutan-tuntutan baru abad pengetahuan menghasilkan sederet prinsip pembelajaran baru dan perilaku yang harus dipraktikkan. Berdasarkan gambaran pembelajan di atas, nampaklah bahwa pentingnya pengembangan profesi guru dalam menghadapi berbagai tantangan ini.

Berdasarkan uraian di atas tergambar bahwa mutu guru merupakan perangkat pengetahuan keterampilan dan perilaku yang harus dimiliki, dihayati dikuasai dan diwujudkan oleh guru dalam melaksanakan tugas keprofesionalannya, ditampilkan melalui unjuk kerja (Kep. Mendiknas No.045/U/2002) menyebutkan kompetensi sebagai seperangkat tindakan cerdas dan penuh tanggung jawab dalam melaksanakan tugas-tugas sesuai dengan pekerjaan tertentu.

Kompetensi guru dapat dimaklumi sebagai kebulatan pengetahuan, keterampilan dan sikap yang berwujud tindakan cerdas dan penuh tanggung jawab dalam melaksanakan tugas sebagai agen pembelajaran. Undang- Undang Sistem Pendidikan Nasional Nomor 20 tahun 2003 pasal 11 ayat 1 mengamanatkan kepada pemerintah pusat dan pemerintah daerah untuk menjamin terselenggaranya pendidikan yang bermutu bagi setiap warga negara. Terwujudnya pendidikan yang bermutu membutuhkan upaya yang terus menerus untuk selalu meningkatkan pendidikan.

Studi yang dilakukan Heyneman \& Loxley pada tahun 1983 di 29 negara menemukan bahwa di antara berbagai masukan (input) yang menentukan mutu pendidikan (yang ditunjukkan oleh prestasi belajar siswa) sepertiganya ditentukan oleh guru. Peranan guru makin penting lagi di tengah keterbatasan sarana dan prasarana sebagaimana dialami oleh negara-negara sedang berkembang. Lengkapnya hasil studi itu adalah: di 16 negara sedang berkembang, guru memberi kontribusi terhadap prestasi belajar sebesar $34 \%$, sedangkan manajemen $22 \%$, waktu belajar $18 \%$ dan sarana fisik $26 \%$. Di 13 negara industri, kontribusi guru adalah $36 \%$, manajemen $23 \%$, waktu belajar $22 \%$ dan sarana fisik 19\% (Dedi Supriadi, 1999: 178).

Rendahnya kompetensi guru di Indonesia disebabkan oleh kompleksitas kondisi yang mengelilingi guru. Adapun kondisi yang dimaksud adalah: masih banyak guru mengajar bukan pada bidang tugasnya. Hal demikian berakibat pada penguasaan dan penyampaian materi tidak dapat berlangsung secara optimal. Alasannya pun sangat bervariasi yakni, di sekolah tidak ada guru lulusan bidang studi tertentu dan demi pemerataan jam mengajar, guru tidak konsen pada tugasnya. guru masih mencari uang melalui pekerjaan lain. Hal ini disebabkan gaji yang diterima tidak mencukupi untuk menopang kebutuhan hidupnya. Konsentrasi kesibukannya justru lebih tinggi untuk pekerjaan lain, bukan pekerjaan yang berkaitan dengan persiapan proses pembelajaran, masih banyak guru gagap teknologi, wawasan kependidikannya rendah, keterampilan mengajar kurang optimal, tidak terampil mengoperasikan komputer, cakrawala pandang wawasan kependidikan yang dapat diakses 
melalui internet tidak dapat tercapai oleh karena belum mengenal internet, motivasi kerja guru yang rendah. Motivasi kerja yang rendah ini dapat disimak melalui sikapnya dalam mempersiapkan RPP, silabus, perangkat penilaian dan perangkat pembelajaran lainnya, pengadaan perangkat pada umumnya hanya berupa foto kopi teman sekolah lain.

Hal lain sebagai indikator motivasi kerja guru rendah adalah belum terciptanya budaya membaca bagi kalangan guru. Artinya, membaca untuk menambah pengetahuan yang berkaitan dengan materi pelajaran dari berbagai referensi ataupun membaca yang berkaitan dengan wawasan kependidikan belum banyak dilakukan oleh sebagian besar guru. Padahal membaca mempunvai kontribusi yang sangat besar bagi pengembangan profesi guru.

Salah satu kebijakan yang dikembangkan oleh pemerintah dalam menangani permasalahan di atas dengan melaksanakan sertifikasi guru. Tujuan dari sertifikasi guru ini diharapkan, seorang guru akan memaksimalkan fungsi, tugas, dan tanggung jawabnya sebagai guru jika ia memperoleh penghargaan yang sepadan dengan apa yang dilakukannya. Dalam hal ini, kesepadanan yang dimaksud berupa kesepadanan antara penghasilan atau finansial dengan beban kerja yang dijalankannya.

Fasli Jalal (2007:1) mengatakan bahwa pendidikan yang bermutu sangat tergantung pada keberadaan guru yang bermutu, yakni guru yang profesional, sejahtera dan bermartabat. Oleh karena itu keberadaan guru yang bermutu merupakan syarat mutlak hadirnya sistem dan praktik pendidikan yang bermutu.

Sejak tahun 2009, jumlah guru yang memperoleh sertifikasi mengalami peningkatan jumlah hingga 100 ribu orang. "Tahun 2009, jumlah guru yang memperoleh sertifikasi sebanyak 100 ribu orang. Pada tahun ini jumlahnya meningkat mencapai 200 ribu.

Tunjangan dana sertifikasi ini, tentu saja tidak diberikan cuma-cuma oleh pemerintah, tetapi ada konsekuensinya bagi tugas dan tanggung jawab guru tersebut. Guru yang telah diberikan sertifikat profesional tersebut harus mengabdikan diri sebagai pioner pencetak sumber daya manusia yang berkualitas (SDM). Hal ini dapat diterima karena dengan besarnya tunjangan yang diterima guru tersebut memungkinkan mereka secara total mengajar di sekolah sehingga tidak perlu lagi mencari tambahan pendapatan di luar profesinya sebagai guru.

Di samping itu, UUGD juga menetapkan berbagai tunjangan yang berhak diterima guru sebagai upaya peningkatan kesejahteraan finansial guru. Kebijakan dalam UUGD ini pada intinya adalah meningkatkan mutu kompetensi guru seiring dengan peningkatkan kesejahteraan mereka. Dalam hal ini sertifikasi guru juga diharapkan dapat meningkatkan mutu pembelajaran. Pertama dan sekaligus yang utama, sertifikasi merupakan sarana atau instrumen untuk mencapai suatu tujuan, bukan tujuan itu sendiri. Perlu ada kesadaran dan pemahaman dari semua pihak bahwa sertifikasi adalah sarana untuk menuju mutu. Sertifikasi bukan tujuan itu sendiri. 
Kesadaran dan pemahaman ini akan melahirkan aktivitas yang benar, bahwa apapun yang dilakukan adalah untuk mencapai mutu. Kalau seorang guru kembali masuk kampus untuk kualifikasi, maka belajar kembali ini untuk mendapatkan tambahan ilmu pengetahuan dan keterampilan, sehingga mendapatkan ijazah S-1. ljazah S-1 bukan tujuan yang harus dicapai dengan segala cara, termasuk cara yang tidak benar melainkan konsekuensi dari telah belajar dan telah mendapatkan tambahan ilmu dan keterampilan baru.

Demikian pula kalau guru mengikuti uji sertifikasi, tujuan utama bukan untuk mendapatkan tunjangan profesi, melainkan untuk dapat menunjukkan bahwa yang bersangkutan telah memiliki kompetensi sebagaimana disyaratkan dalam standar kemampuan guru. Tunjangan profesi adalah konsekuensi logis yang menyertai adanya kemampuan yang dimaksud.

Dengan menyadari hal ini maka guru tidak akan mencari jalan lain guna memperoleh sertifikat profesi kecuali mempersiapkan diri dengan belajar yang benar untuk menghadapi uji sertifikasi. Kedua, konsistensi dan ketegaran pemerintah. Sebagai suatu kebijakan yang bersentuhan dengan berbagai kelompok masyarakat akan mendapatkan berbagai tantangan dan tuntutan.

Berdasarkan pengamatan awal lapangan di SD Negeri 011 Sukajadi Pekanbaru diduga terdapat beberapa fenomena yang menarik. Fenomena tersebut antara lain sebagai berikut:

1. Guru-guru SD Negeri 011 Sukajadi Pekanbaru yang disertifikasi telah mengikuti sosialisasi pelatihan sehubungan dengan KTSP. KTSP adalah suatu kurikulum pembelajaran menghendaki siswa aktif, partisipatif dan menyenangkan, guru sebagai fasilitator, namun paradigma baru pembelajaran KTSP belum sepenuhnya di laksanakan, metode ceramah masih mendominasi dalam pelaksanaan proses pembelajaran sehingga dikhawatirkan mutu pendidikan yang menjadi tujuan tidak akan pernah tercapai.

2. Antara guru kelas yang paralel terkadang tidak sejalan dalam melaksanakan proses pembelajaran di kelasnya sehingga peserta didik menjadi pasif dan belajar dari materi di dalam buku semata.

3. Guru kelas yang telah disertifikasi terkadang datang terlambat dan pulang cepat dengan alasan sudah habis jam mengajar pada hal jam dinas guru masih berlangsung.

4. Dalam proses pembelajaran guru kelas telah berusaha memberikan kesempatan yang sama untuk berpartisipasi aktif, bertanya, memberikan tanggapan kritis, menjawab pertanyaan-pertanyaan. Namun, tidak semua siswa mau menggunakan kesempatan yang diberikan guru, yang terlibat aktif selalu siswa tertentu saja.

5. Peserta didik dalam menyelesaikan tugas kurang bertanggung jawab dan berdiskusi/berkelompok hanya dengan teman dekatnya saja.

6. Peserta didik sangat responsif, mudah tersinggung, suka berkelahi, mengganggu teman mencoret meja kursi dengan Tip-Ex

Untuk menjawab dan membuktikan berbagai pertanyaan yang muncul berkaitan dengan keprofesionalan guru yang telah disertifikasi, peneliti tertarik melakukan kajian mendalam secara ilmiah melalui penelitian ini. Penelitian ini berjudul "Peranan Sertifikasi Guru dalam Meningkatkan Mutu Pendidikan di 
Sekolah Dasar Negeri 11 Sukajadi Pekanbaru". Penelitian ini bertujuan untuk mengetahui: Pelaksanaan pembelajaran oleh guru yang telah disertifikasi dalam rangka meningkatkan mutu pembelajaran di SD Negeri 011 Sukajadi Pekanbaru.

\section{Tujuan Penelitian}

Penelitian ini bertujuan untuk mengetahui: Pelaksanaan pembelajaran oleh guru yang telah disertifikasi dalam rangka meningkatkan mutu pembelajaran di SD Negeri 011 Sukajadi Pekanbaru.

\section{Metodologi Penelitian}

Sesuai dengan masalah dan fokus penelitian di atas, maka penelitian ini menggunakan pendekatan kualitatif. Penelitian kulitatif adalah penelitian yang dilakukan dengan latar belakang yang wajar dan alamiah serta holistik. Penelitian kualitatif berusaha melihat, mencermati, dan menghayati masalah yang akan diteliti sebagai fenomena yang kompleks yang harus diteliti secara holistik atau menyeluruh (PPS UNP, 2004: 18).

Untuk memperoleh gambaran tentang penelitian kualitatif, ada beberapa ciri pokok penelitian ini yakni (1) lingkungan alamiah sebagai sumber data langsung, (2) manusia merupakan alat atau instrumen utama pengumpul data, (3) analisis data dilakukan secara induktif, dan (4) penelitian bersifat deskriptif analitik (Arikunto, 2007: 38-39).

Berdasarkan ciri-ciri yang terkandung dalam penelitian kualitatif sebagaimana diuraikan di atas, maka peneliti akan memaparkan sesuatu yang benar-benar terjadi di lapangan. Data yang peneliti peroleh dari hasil observasi, wawancara, dan dokumentasi dipaparkan secara gamblang dengan didukung oleh teori-teori yang relevan. Dalam mengumpulkan data, peneliti merupakan instrumen utama. Di samping itu, pemaparan hasil analisis dimulaui dengan temuan-temuan khusus yang pada akhirnya baru ditarik simpulan umum. Karena penelitian kualitatif bersifat deskripsi analitik maka pemaran hasil temuan dan hasil analisis dengan menggunakan bahasa atau

Teknik dan Alat Pengumpul Data

Teknik pengumpul data dilakukan dengan cara observasi langsung ke lapangan dan wawancara mendalam (depth interview) dengan informan melalui dokumentasi.

\section{Obsevasi}

Sejak awal studi pendahuluan telah di lakukan observasi terutama untuk melihat kondisi objektif lokasi penelitian. Di samping itu, observasi dilakukan untuk mengamati proses pembelajaran yang dilakukan oleh guru yang bersetifikasi khususnya.

1) Mengamati secara langsung pelaksanaan proses pembelajaran yang dilaksanakan guru yang telah disertifikasi yang dilakukan di kelas mulai dari membuka pelajaran, menyampaikan materi pembelajaran serta mengakhiri pembelajaran. Hal ini dilakukan untuk melihat bagaimana proses pembelajaran dalam mengembangkan pemahaman siswa tentang meteri yang disajikan. Untuk kepentingan observasi ini, peneliti berpedoman pada format observasi yang telah dirancang sebelum turun ke lapangan mengumpulkan data. Di samping format 
pengamatan, peneliti juga berpedoman pada RPP yang disiapkan oleh para guru tersebut. Apakah langkah-langkah yang terdapat dalam RPP telah dijalankan dengan baik dan maksimal.

2) Di samping mengobservasi pelaksanaan pembelajaran, observasi juga ditujukan untuk melihat Interaksi eduktif antara guru dengan siswa dalam mengembangkann pemahaman siswa tentang materi pelajaran. Penelitian ini untuk memperoleh data yang baik akurat maka kegiatan obsevasi ini di lakukan berulangkali sampai di peroleh semua data yang di perlukan.Hal tersebut memiliki keuntungan dimana informan yang diamati terbiasa dengan kehadiran peneliti sehingga informan berperilaku apa adanya.

3) Sebagaimana dinyatakan pada bagian terdahulu bahwa siswa juga merupakan satu komponen yang harus diobservasi. Observasi yang dilakukan kepada siswa bertujuan untuk mengetahui lebih dalam benarkah guru yang sudah disertifikasi dalam menjalankan perannya dengan maksimal dalam rangka meningkatkan mutu pendidikan. Sama halnya dengan observasi pada guru, pada saat mengobservasi siswa dibutukan juga format pengamatan agar pengamatan yang dilakukan terfokus pada kebutuhan data yang ingin dikumpulkan.

4) Observasi terhadap siswa tidak saja dilakukan di dalam kelas saat mereka mengikuti proses pembelajaran, tetapi juga dilakukan di luar kelas. Tujuannya melihat relevansi apa yang mereka pelajari di kelas dengan pola tingkah laku siswa di luar kelas terutama dalam lingkungan sekolah. Dengan melakukan observasi di luar kelas akan terlihat hubungan siswa dengan siswa, siswa dengan guru dan personil lainnya di lingkungan sekolah.

\section{Wawancara}

Wawancara mendalam secara umum adalah proses memperoleh keterangan untuk tujuan penelitian dengan cara tanya jawab sambil bertatap muka antara pewawancara dengan informan atau orang yang diwawancarai, dengan atau tanpa menggunakan pedoman wawancara, di mana pewawancara dan informan terlibat dalam kehidupan sosial yang relatif lama (Burhan, 2007:108).

Dalam penelitian ini peneliti melakukan wawacara dengan berbagi pihak di antaranya kepala sekolah untuk memperoleh gambaran pelaksanaan proses pembelajaran dan profesionalisme garu dalam proses pelaksanaan pembelajaran. Di samping itu, dengan melakukan wawancara kepada kepala sekolah juga didapatkan informasi tentang persoalan atau masalah siswa mengenai prestasinya terutama sikap dan tingkah lakunya. Berikutnya juga diperoleh data mengenai hubungan guru dengab guru, guru dengan dengan siswa, dan siswa dengan siswa.

Kemudian wawancara dilakukan dengan guru yang telah diserrtifikasi terutama mengenai pemahan mereka tentang pembelajaran B. Indonesia, matematika, dan IPA. Dengan dilakukan wawancara terfokus pada tiga mata pelajaran ini, peneliti juga mendapatkan informasi tentang kendala dan upayaupaya yang dilakukan guru mengembangkan pemahaman siswa pada mata pelajaran itu sendiri. 
Untuk menjaring data mengenai pemahaman siswa, peneliti juga melakukan wawancara dengan siswa bagimana pemahaman mereka tentang mata pelajaran. B Indonesia, matematika, dan IPA yang diajarkan oleh guru yang telah disentifikasi. Informasi yang telah diperoleh, diolah, dan konfirmasikan melalui tahap triangulasi dan member check. Hal ini dilakukan untuk memperoleh masukan mengenai kesesuaian data tersebut dengan informan penelitian ini. Untuk meperoleh data penunjang tentang persoalan yang berkaitan dengan kesadaran dan pemahaman siswa tentang pembelajaran dalam mata pelajaran B.Indonesia, metematika, dan IPA.

\section{Studi dokumentasi}

Dokumentasi adalah metode pengumpulan data dengan mengumpulkan sejumlah fakta dan data sosial yang tersimpan dalam bahan yang berbentuk dokumen (Burhan, 2007:121). Dokumentasi dalam penelitian ini dengan mengumpulkan dokumen yang berhubungan dengan manajemen sekolah dan pembelajaran guru di sekolah SD Negeri 011 Sukajadi Pekanbaru.

Alat pengumpul data utama adalah peneliti sendiri dan menggunakan instrumen wawancara, observasi, dan dokumentasi. Pendekatan dengan informan dilakukan dengan secara periodik peneliti berkunjung ke sekolah kemudian ke kelas untuk melihat secara langsung proses kegiatan belajar mengajar yang dilaksanakan oleh guru-guru. Selain itu peneliti juga menggunakan murid-murid, di sekolah tersebut sebagai alat pengumpul data sesuai dengan arahan peneliti. Hal ini dilakukan sebagai data tambahan untuk memastikan bahwa data yang terkumpul menjadi terpercaya (valid).

\section{PEMBAHASAN}

Dari hasil temuan didapat bahwa guru yang telah disertifikasi di SDN 11 Sukajadi Pekanbaru telah menguasai bahan ajar dengan baik dan melaksanakan/membuat rencana program pembelajaran (RPP), silabus serta melaksanakan evaluasi pendidikan dengan baik. Hal ini dijumpai pada saat melaksanakan pembelajaran dan penilaian atau meremedial siswa yang tidak lulus dengan baik sehingga menunjukkan hasil belajar siswa yang lebih baik. Hal ini sesuai dengan pendapat Kunandar (2007: 63-67) yang mengemukakan bahwa untuk mampu melaksanakan tugas mengajar dengan baik, guru harus memiliki kemampuan profesional, yaitu terpenuhinya 10 kompetensi guru, yang meliputi: a. Menguasai bahan meliputi: (1) Menguasai bahan bidang studi dalam kurikulum sekolah. (2) Menguasai bahan pengayaan/penunjang bidang studi. b. Mengelola program belajar mengajar, meliputi: (1) Merumuskan tujuan intsruksional. (2) Mengenal dan dapat menggunakan prosedur instruksional yang tepat. (3) Melaksanakan program belajar mengajar. (4) Mengenal kemampuan anak didik. c. Mengelola kelas, meliputi: (1) Mengatur tata ruang kelas untuk pelajaran. (2) Menciptakan iklim belajar mengajar yang serasi. d. Menggunakan media atau sumber, meliputi: (1) Mengenal, memilih dan menggunakan media. (2) Membuat alat bantu pelajaran yang sederhana. (3) Menggunakan perpustakaan dalam proses belajar mengajar. (4) Menggunakan micro teaching untuk unit program pengenalan lapangan; e. Menguasai landasan-landasan pendidikan. f. Mengelola interaksi-interaksi belajar mengajar. g. Menilai prestasi siswa untuk kepentingan pelajaran. h. Mengenal fungsi layanan dan program 
bimbingan dan penyuluhan: a. Mengenal fungsi dan layanan program bimbingan dan penyuluhan; b. Menyelenggarakan layanan bimbingan dan penyuluhan. i. Mengenal dan menyelengarakan administrasi sekolah. j. Memahami prinsipprinsip dan menafsirkan hasil penelitian pendidikan guna keperluan pengajaran. Di samping 10 kompetensi guru di atas, guru yang telah disertifikasi di SDN 011 Sukajadi Pekanbaru juga dituntut untuk memiliki 4 kompetensi guru profesional, yakni: kompetensi pedagogik, kepribadian, profesional, dan sosial.

\section{Kompetensi Pedagogik Guru yang Sudah disertifikasi di SD Negeri 011 Sukajadi Pekanbaru.}

Dari temuan penelitian diketahui bahwa kompetensi pedagogik guru-guru SDN 011 Sukajadi yang telah disertifikasi sudah terlaksana dengan baik. Hal ini terlihat dari beberapa komponen yang telah dilaksanakan oleh guru-guru yang sudah disertifikasi. Adapun komponen tersebut adalah: 1) memahami karakteristik peserta didik dari berbagai aspek, sosial, moral, kultural, emosional, dan intelektual, 2) memahami gaya belajar dan kesulitan belajar peserta didik, 3) memfasilitasi pengembangan potensi peserta didik, 4) menguasai teori dan prinsip belajar serta pembelajaran yang mendidik, 5) mengembangkan kurikulum yang mendorong keterlibatan peserta didik dalam pembelajaran, 6) merancang pembelajaran yang mendidik, 7) melaksanakan pembelajaran yang mendidik, 8) memahami latar belakang keluarga dan masyarakat peserta didik dan kebutuhan belajar dalam konteks kebhinekaan budaya, 9) mengevaluasi proses dan hasil pembelajaran.

Di samping itu, perangkat pembelajaran (RPP), evaluasi hasil belajar, dan pengembangan peserta didik. Sebagaimana tertera pada UU SiSDiknas (2003 pasal 39) dinyatakan "Pendidik merupakan tenaga profesional yang bertugas merencanakan dan melaksanakan proses pembelajaran, menilai hasil pembelajaran, melakukan pembimbingan dan pelatihan. Hal dapat dilihat dari hasil temuan penelitian di lapangan bahwa Semua guru SDN 011 Sukajadi yang telah disertifikasi mempersiapkan RPP sebelum melaksanakan kegiatan pembelajaran. Sebelum tahun ajaran baru, Kepala Sekolah senantiasa meminta guru mengumpulkan RPP yang akan digunakan pada semester tersebut. Setelah diperiksa, kepala sekolah mengembalikan dan meminta guru merevisi dan melengkapi jika RPPnya belum baik. Hal ini dilakukan berkaitan dengan peningkakan kualitas pendidikan. Di samping itu, SDN 011 Sukajadi sekolah berstandar internasional (SDI) sehingga setiap guru harus mendukung program tersebut.

Evaluasi hasil belajar juga dilakukan dengan cara lengkap dan bervariasi. Hal ini terlihat jenis tagihan yang diberikan guru kepada siswa. Penilaian hasil belajar dilakukan secara menyeluruh (komprehensif). Ada penilaian aspek kognitif dengan memberikan soal dengan bentuk yang variatif (objektif, esai, tes lisan) dan tingkat Taksonomi Bloom yang bervariasi juga. Hal ini berarti bahwa guru SDN 011 Sukajadi yang telah disertifikasi mampu menerapkan anjuran yang telah digariskan dan UU SiSDiknas sebagaimana dalam Pasal 19 ayat (3): (1) penilaian hasil pembelajaran pada jenjang pendidikan dasar dan menengah menggunakan berbagai teknik penilaian sesuai dengan kompetensi dasar yang harus dikuasai. (2) Teknik penilaian sebagaimana dimaksud pada ayat (1) dapat 
berupa tes tertulis, observasi, tes praktek, dan penugasan perseorangan atau kelompok. (3) Untuk mata pelajaran selain kelompok mata pelajaran ilmu pengetahuan dan teknologi pada jenjang pendidikan dasar dan menengah, teknik penilaian observasi secara individual sekurang-kurangnya dilaksanakan satu kali dalam satu semester. (4) Penggunaan metode dan penilaian yang bervariasi berkaitan dengan pemahaman terhadap peserta didik. Pemahaman peserta didik merupakan salah satu kompetensi pedagogik yang harus dimiliki guru. Sedikitnya terdapat empat hal yang harus dipahami guru dari peserta didiknya, yaitu tingkat kecerdasan, kreativitas, cacat fisik, dan perkembang kognitif (Elmulyasa, 2008: 78).

\section{Kompetensi Kepribadian Guru yang Sudah disertifikasi di SD Negeri 011 Sukajadi Pekanbaru.}

Dari pengamatan langsung dan hasil wawancara dengan kepala sekolah bahwa guru yang sudah disertifikasi merupakan pribadi-pribadi yang menyenangkan, melindungi, dan memberi rasa nyaman bagi siswa. Sebagai pembuktian, pada saat kegiatan pembelajaran berlangsung tidak ada siswa yang merasa tertekan dan takut dalam belajar. Suasana pembelajaran berlangsung nyaman. Keakraban siswa dengan guru berlangsung baik, dan tetap saling menghormati.

Guru juga sudah menampilkan sosok yang berwibawa, bijaksana, dan memberikan keteladanan bagi peserta didik. Selama pengamatan peneliti lakukan, guru tidak marah-marah, siswa senang pada saat belajar, guru memberikan contoh tauladan yang baik dan berakhlak mulia kepada siswanya dan disetiap tugas yang diberikan oleh guru dikerjakan oleh siswa. Di samping itu, siswa mengikuti pelajaran dengan serius. Hal ini menunjukkan bahwa guru sudah berwibawa, arif dan tauladan bagi siswa.

Hal ini sesuai dengan Penjelasan Pasal 28 ayat (3) butir b, dikemukakan bahwa yang dimaksud dengan kompetensi kepribadian adalah kemampuan pribadi yang mantap, stabil, dewasa, arif, dan berwibawa, menjadi teladan bagi peserta didik, dan berakhlak mulia.

Dari uraian di atas, setiap guru dituntut memiliki kompetensi kepribadian yang memadai, bahkan kompetensi ini akan melandasi bagi kompetensikompetensi lainnya. Terkait dengan masalah ini, para guru SDN 011 Sukajadi pekanbaru yang telah disertifikasi telah mengaplikasikan kompetensi kepribadian ini dengan baik. Adapun empat kepribadian yang telah dilaksanakan oleh guru adalah: 1) menampilkan diri sebagai pribadi yang mantap, stabil, dewasa, arif, dan berwibawa, 2) menampilkan diri sebagai pribadi yang berakhlak mulia dan sebagai teladan bagi peserta didik dan masyarakat, 3) mampu mengevaluasi kinerja sendiri (tindakan reflektif), dan 4) mampu mengembangkan diri secara berkelanjutan.

\section{Kompetensi Sosial Guru yang Sudah disertifikasi di SD Negeri 011 Sukajadi Pekanbaru}

Berdasarkan temuan yang peneliti lakukan terhadap guru-guru di SDN 
011 Sukajadi pekanbaru Guru yang telah disertifikasi telah mengaplikasikan kompetensi sosial ini dengan baik. Adapun empat kompetensi sosial yang telah dilaksanakan oleh guru adalah: 1) dapat berkomunikasi secara simpati dan empati dengan peserta didik, orang tua peserta didik, sesama pendidik dan tenaga kependidikan, dan masyarakat 2) berkontribusi terhadap pengembangan pendidik di sekolah dan masyarakat; di tingkat lokal, regional, nasional, dan global, 3) berkontribusi terhadap pengembangan pendidikan di tingkat lokal, regional, nasional, dan global, dan 4) memanfaatkan teknologi informasi dan komunikasi (ICT) untuk berkomunikasi dan pengembangan diri.

Sebagaimana yang telah peneliti paparkan di atas, terjalin hubungan sosial yang baik antara guru dengan siswa, antara guru dengan sesama guru, guru dengan kepala sekolah, guru dengan tenaga administrasi dan penjaga sekolah. Dari pengamatan langsung yang peneliti lakukan di dalam kelas pada saat guru mengajar terlihat jelas terjalin hubungan sosial dan emosional antara guru dan siswa. Pada saat pembelajaran berlangsung, siswa memberikan respon yang baik terhadap kegiatan pembelajaran yang diberikan oleh guru. Pada saat di luar kelas pun, siswa mau bersenda gurau dengan guru, bahkan siswa juga tidak sungkan makan di kantin bersama guru-gurunya.

Di samping itu, hubungan sosial antara sesama guru terlihat akrab. Pengamatan langsung yang peneliti lakukan di ruang majelis guru menunjukkan bahwa guru saling berkomunikasi membicarakan hal-hal yang berkaitan dengan kegiatan pembelajaran di kelas dan masalah-masalah yang ditemui siswa dalam belajar. Dari pengamatan dan wawancara yang dilakukan terkumpul data bahwa tidak ada jarak yang membedakan antara satu guru dengan guru yang lainnya. Guru senior sering membimbing guru muda. Demikian juga, guru yang muda tidak sungkan bertanya dan berdiskusi tentang pelajaran dan permasalahan yang ditemui dalam kegiatan pembelajaran. Hubungan guru dengan tenaga administrasi dan penjaga kantin sekolah pun terjalin dengan akrab. Dari pengamatan langsung yang peneliti lakukan di kantin sekolah, terlihat bahwa antara guru dengan penjaga kantin sangat erat. Mereka saling bercanda dan berbincang-bincang tentang banyak hal.

Dari uraian di atas diketahui bahwa kompetensi sosial adalah kemampuan guru sebagai bagian dari masyarakat untuk berkomunikasi dan bergaul secara efektif dengan peserta didik, sesama pendidik, tenaga kependidikan, orang tua/wali peserta didik, dan masyarakat sekitar. Hal tersebut diuraikan lebih lanjut dalam RPP tentang guru, bahwa kompetensi sosial yang sekurang-kurangnya memiliki kompotensi untuk:

a. Berkomunikasi secara lisan, tulisan, dan isyarat.

b. Menggunakan teknologi komunikasi dan informasi secara fungsional.

c. Bergaul secara efektif dengan peserta didik, sesama pendidik, tenaga kependidikan, orang tua/wali peserta didik, dan

d. Bergaul secara santun dengan masyarakat sekitar (Mulyasa, 2008:135).

Dari kehidupan sosial masyarakat dan lingkungannya. Oleh karena itu, 
guru dituntut untuk memiliki kompetensi sosial yang memadai, terutama dalam kaitannya dengan pendidikan, yang tidak terbatas pada pembelajaran di sekolah, tetapi juga pada pendidikan yang terjadi dan berlangsung di masyarakat.

\section{SIMPULAN}

Dari pembahasan di atas bahwa keberadaan guru yang berkualitas merupakan syarat mutlak hadirnya sistem dan praktik pendidikan yang berkualitas. Dari hasil penelitian yang telah dilakukan, dapat diambil kesimpulan sebagai berikut:

Dari pengumpulkan data yang peneliti lakukan baik studi dokumentasi, observasi, dan wawancara diperoleh jawaban mengenai peranan guru yang telah disertifikasi dalam meningkatkan kualitas pembelajaran di SDN 011 Sukajadi Pekanbaru telah melakukan bahan ajar dengan baik dan melaksanakan/membuat rencana program pembelajaran (RPP), silabus serta melaksanakan evaluasi pendidikan dengan baik. Seperti melaksanakan penilaian atau meremedial siswa yang tidak lulus dengan baik sehingga menunjukkan hasil belajar siswa yang lebih baik.

Di samping itu, para guru SDN 11 Sukajadi Pekanbaru yang telah disertifikasi telah melaksanakan empat kompetensi profesional yakni kompetensi pedagogik, kepribadian, profesional dan sosial.

\section{Kompetensi Pedagogik}

Pelaksanaan kompetensi pedagogik oleh para guru SDN 011 Sukajadi Pekanbaru telah berjalan dengan baik. Pengelolaan pembelajaran berjalan dengan baik. Proses pembelajaran berlangsung sesuai dengan alokasi waktu yang tersedia. Kemampuan pengelolaan kelas juga berjalan dengan baik sehingga saat proses pembelajaran berlangsung antara guru dan siswa saling bekerja sama untuk mencapai tujuan pembelajaran yang ditetapkan. Di samping itu, pemahaman guru terhadap peserta didik juga dipertimbangkan. Metode penyampaian materi pelajaran disesuaikan dengan kemampuan siswa yang berbeda sehingga guru tidak hanya menerapkan satu metode saja, tetapi menggunakan metode yang bervariasi. Demikian juga dengan pemberian evaluasi juga bervariasi baik tingkat kemampuan yang diujikan dan jenis tes yang diberikan

\section{Kompetensi Kepribadian}

Guru-guru SDN 011 Sukajadi Pekanbaru memiliki kepribadian yang mantap, stabil, dan dewasa. Hal ini berpengaruh pada prestise guru tersebut di mata siswa. Guru-guru tersebut dijadikan panutan dan model bagi siswa. Kharisma guru ini berdampak pada patuh tidaknya siswa pada mereka. Para guru SDN 011 Sukajadi Pekanbaru yang telah disertifikasi (informan Penelitian) menegakkan disiplin, arif, dan berwibawa. Meskipun terjalin hubungan sosial yang baik antara guru dengan siswa bukan berarti siswa dapat melakukan semau hatinya tanpa kontrol. Namun, di SDN 011 Sukajadi ini, guru menegakkan disiplin secara arif atau mendidik. Siswa juga akan mendapat 
teguran, hukuman jika melakukan kesalahan. Di samping itu, jika siswa mengukir prestasi juga mendapat penghargaan positif dari para guru.

\section{Kompetensi Profesional}

Pada saat kegiatan pembelajaran berlangsung, kompetensi profesional telah dilaksanakan dengan baik. Guru menguasai pembelajaran dengan baik, mengorganisasikan dan menjelasakan materi pelajaran dengan terstruktur. Pembelajaran dilaksanakan dengan menggunakan metode yang bervariasi, melakukan evaluasi hasil belajar yang bervariasi sehingga dapat mewadahi kemampuan siswa yang bervariasi. Berikutnya guru juga menggunakan metoda yang disesuaikan dengan karakteristik materi pelajaran.

\section{Kompetensi Sosial}

Hubungan antara guru dengan siswa, antara guru dengan sesama guru, guru dengan kepala sekolah, guru dengan tenaga administrasi dan penjaga sekolah terjalin dengan baik. Pada saat kegiatan belajar mengajar siswa memberikan respon yang baik terhadap kegiatan pembelajaran yang diberikan oleh guru. Pada saat di luar kelas pun, siswa mau bersenda gurau dengan guru, bahkan siswa juga tidak sungkan makan di kantin bersama guru-gurunya. Guru juga saling membicarakan hal-hal yang berkaitan dengan kegiatan pembelajaran di kelas dan masalah-masalah yang ditemui siswa dalam belajar. Sehingga tidak ada jarak yang membedakan antara satu guru dengan guru yang lainnya. Guru senior sering membimbing guru muda. Demikian juga, guru yang muda tidak sungkan bertanya dan berdiskusi tentang pelajaran dan permasalahan yang ditemui dalam kegiatan pembelajaran. Hubungan guru dengan tenaga administrasi dan penjaga kantin sekolah pun terjalin dengan akrab.

\section{DAFTAR PUSTAKA}

Anwar Arifin, 2006 Eksistensi dan Implementasi http://elpramwidya.wordpress.com/2009/01/09/

Azmi. 2006. Handout Penelitian Kualitatif : Naturalistic Inquiry Materials Oleh D. D. William, Ph.D. (saduran). Padang: Universitas Negeri Padang.

Benny. (2007) Model Disain Sistim Pembelajaran. Jakarta. Dian Rakyat

Bungin, Burhan. 2005. Analisis Data Penelitian Kualitatif. Jakarta, PT. Raja Grafindo Persada.

Dimyati dan Mudjiono. 2009. Belajar dan Pembelajaran. Jakarta: Rineka Cipta.

Djamarah, Syaiful Bahri dan Aswin. 2006. Strategi Belajar Mengajar. Jakarta: Rineka Cipta.

E, Mulyasa, 2008. Standar Kompetensi dan Sertifikasi Guru, Bandung RoSBa Karya.

Farida Sarimaya, 2008 Sertifikasi Guru, Apa, Mengapa dan Bagaimana?, Yrama 
Media.

Hamalik, Oemar. 2006. Pendidikan Guru Berdasarkan Pendekatan Kompetensi. Jakarta: Bumi Aksara.

Isjoni. (2007) Pengembangan Profesional Guru. Pekanbaru. Cendikia Insani

Ki, Supriyoko. 2007. Meningkatkan Kompetensi Pedagogik Duru TK dan SD. Pekanbaru. Fasilitator

Kunandar. 2007. Guru Profesional, Implementasi KTSP dan Sukses dalam Sertifikasi Guru. Jagakarsa. Raja Grafindo Persada.

Miles dan Huberman. 1992. Analisa Data Kualitatif. Jakarta. Universitas Indonesia.

Margono, S. 2007. Metodologi Penelitian Pendidikan. Jakarta: Rineka Cipta.

Moleoung, J Lexy. 2000. Metodologi Penelitian Kualitatif. Bandung: Remaja Rosda Karya.

Purwanto, Ngalim. 2001. Prinsip-Prinsip dan Teknik Evaluasi Pengajaran. Bandung: Remaja RoSBakarya.

Slameto. 2003. Belajar dan Faktor yang Mempengaruhinya.Jakarta: Rineka Cipta.

Sugiyono. 2005. Memahami Penelitian Kualitatif Bandung. CV. Alfabeta

Sumardi Suryabrata. 2001. Psikologi Pendidikan. Jakarta: Raja Grafindo Persada.

Undang- Undang no 14 Tahun 2005 Tentang Guru dan Dosen.

Universitas Negeri Padang. 2004. Buku Panduan Penulisan Tesis dan Padang: PPS Universitas Negeri Padang.

Zainal, Aqib. 2009. Menjdi Guru Yang Profesional. Bandung. Yrama Widia. 